\title{
Information Delivery Strategies and the Rural Student
}

\section{Sharon M. West}

Distance education was developed to meet the educational needs of a diverse population who could not come to the traditional campus. Along with this development has been the demand for library services for these distance learners. Many of them are rural residents without easy access to libraries of any size. This paper outlines how a university library in a predominantly rural setting implemented a distance delivery program by using primarily electronic technology and by replacing traditional library services with an information brokering and document delivery service.

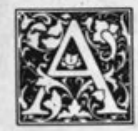

s numerous studies and papers document, colleges and universities developed distance education to meet the educational needs of a diverse population who, for whatever reason, could not come to the traditional campus. ${ }^{1}$ Distance education has taken many forms, from branch campuses with full facilities to courses offered by video or teleconferencing.

Along with the development of distance education has been the corresponding demand for library services for distance learners. Libraries have a long history of providing support to extension education. In 1959 Arthur T. Hamlin pointed out that some college and university libraries had been providing support to distance learners since $1916 .{ }^{2}$ In the 1950 s over thirty universities were providing library extension services. $^{3}$

Since a prime target population for distance education has been rural students, providing library and information services to distance learners has, by default, meant providing these services to rural populations. As Glenn R. Wilde points out, a major problem of rural degree programs has been the lack of information resources to support them. ${ }^{4}$ One of the aims of a university education is to teach students lifelong learning skills-such as using information resources. Evidence suggests that this is not the case for distance students. Russell L. and Judith Dobson point out that critics of extended graduate programs often argue that students do not use library resources. ${ }^{5}$ The profession has responded by developing guidelines and programs which attempt to serve these students. Most recently, the ACRL Guidelines for Extended Campus Library Services has been revised and reissued. ${ }^{6}$

The guidelines assert that the provision of facilities, equipment, and communication links may vary and "should be appropriate to programs offered."7 However, all examples show a bias for providing physical facilities. This disposition toward the provision of physical library facilities for distance learners has been echoed by such authors as Marie Kascus and William Aguilar who, in 1988, listed four options for providing access to library and bibliographic services. ${ }^{8}$ These options involved the development of a 
branch library, the use of a local public library, or the development of a trunk delivery system, which was a type of bookmobile service for students. The fourth option proposed that the campus library assume centrally all responsibility for its distant students.

The tradition of using the public library as a focal point for meeting the information needs of distance learners is well rooted in the philosophic premise that public libraries can be, as William Critchley has said, "the working man's university." "In 1932 Sarah B. Askew reported the attempt of the Public Library Commission of New Jersey to provide public library service to extension students. ${ }^{10}$ Almere L. Scott called upon academic and public libraries to cooperate in preventing unnecessary expense and duplication." A well-known contemporary experiment for providing service to distance students using public libraries is the Intermountain Community Learning and Information Services (ICLIS) project conducted by Utah State University. Funded by the Kellogg Foundation, ICLIS was intended to show how modern hi-tech equipment could help meet the informational needs of rural students in Utah, Montana, Colorado, and Wyoming. The foundation of the project rested upon the local rural public library, which was selected to become the Community Learning and Information Center. ${ }^{12}$ This project attempted not so much to change the manner in which library and information services were delivered as to change the role and nature of the public library in these communities. ICLIS attempted, rather successfully, to use the public library as a partner in the distance educational environment.

While few librarians would dispute the fact that it is better for students to have direct physical access to a library, far more rural students than perhaps we wish to admit have little or no access to a local library, public or otherwise. Even with a local library present, its hours of operation and its collection size may not make it useful for distance learners' needs. In 1989, approximately 8.2 million people lived in communities of less than 4,999 people. ${ }^{13}$ While there were almost 4,000 libraries in these communities, 14 percent of the libraries reported collection sizes of less than 5,000 volumes and 32 percent reported collection sizes of 5,000 to 9,999 volumes. ${ }^{14}$ Libraries of these sizes will not usually meet the needs of a student involved in higher education.

If a college or university wishes to meet the library and information needs of distance learners, but cannot provide a physical facility, it must exercise Kascus and Aguilar's fourth option-by providing all services centrally. But as Robert M. Cookingham pointed out in 1982 , any attempt to do this must address the three factors of awareness, access, and availability. ${ }^{15}$

\section{One of the aims of a university education is to teach students lifelong learning skills-such as using information resources. Evidence suggests that this is not the case for distance students.}

The University of Alaska, Fairbanks (UAF) faced such a situation in 1987, due to a variety of budgetary factors beyond the control of the library program and the university itself. This paper outlines how the Elmer E. Rasmuson Library at UAF implemented a distance delivery program by using primarily electronic communication technology and replacing traditional library service with an Extended Campus Services center that now functions as an information broker and delivery service.

\section{BACKGROUND}

UAF is the state's land-grant institution and the foremost research center in Alaska. Established in 1917, UAF was originally the state's sole institution of higher education. In the 1970s the decision was made to extend the higher education function to other locations through the establishment of university units in Juneau and Anchorage. The university also added community college 
campuses in many places throughout Alaska. Each of these units had its own administrative structure, faculty, curriculum and support services, including libraries. Some campuses developed substantial libraries while other campuses had virtually no library service. The university tried to supply library service through a variety of means, but as Margaret $\mathrm{K}$. Wood and Rosemary E. Ross have both reported, the success of these ventures varied enormously. ${ }^{16}$

In 1987, because of extreme budget reductions, the statewide system radically restructured the university, eliminating as many administrative units as possible, yet retaining the instructional missions of the local colleges. UAF was no longer solely a residential campus in Fairbanks. It also became a statewide university unit with branch campuses, rural education centers, research centers, the sites of the Cooperative Extension Service, and the Marine Advisory Program. Other communities which had not previously been part of the University of Alaska developed their own educational institutions, which, through consortium arrangements, became part of UAF. When the reorganization was complete, the university had made the commitment to offer courses and locate faculty and staff throughout more than 500,000 square miles of the state, an area approximately the combined size of Texas and California (see figure 1).

Unlike other extended campus programs offered in the lower 48 states, where there may be a gradual thinning of both population and available services from a core zone, in Alaska an abrupt drop-off occurs outside the urban areas. In other U.S. states, rural may mean cities with a population under 2,500 people. In Alaska, rural means villages not located on any road system, with access only by air. Since Alaska has only 5,679 ( 3,003 unpaved; 2,676 paved) miles of roads, most of the students, faculty, and staff in extended UAF live, by definition, in rural areas.

These students do not attend class by commuting to Fairbanks or to one of the branch campus sites. Instead students pursue their course work primarily through audioconferencing. For the period fall 1988 through spring 1990, there were 15,548 distant students enrolled in audioconferenced courses. These students were pursuing degrees at all levels-associate, baccalaureate, and master's.

As noted above, some former community colleges had developed libraries prior to restructuring. These included the Kuskokwim Campus in Bethel and the Northwest Campus in Nome. As restructuring took hold, the community and university campus of Kotzebue jointly formed a library for the Chukchi Campus. Barrow, which had never had a public or academic library, developed one to support the North Slope Higher Education Center. Altogether, in 1987, these libraries held only 51,098 volumes, of which 30,145 were in one library. ${ }^{17}$

Most rural students are Native Americans and live in villages with limited or no local library services. The Chukchi campus in Kotzebue serves a population of 6,000 people, of whom 88 percent are Inupiaq Eskimo and other Alaska native groups. The Kuskokwim Campus serves approximately 4,000 people, many of whom still speak Yup'ik Eskimo as their primary language and retain their traditional cultural values. For many of the students, distance delivery courses may represent their first contact with higher education.

American natives, including Alaskan natives, have traditionally relied upon oral tradition to record the achievements and activities of their culture. Elizabeth Brandt, a sociolinguist, has theorized that native Americans have an aversion to the written record because it places a barrier between experience and truth. ${ }^{18}$ Whatever the reason, Susan Hollaran has stated that native Americans are not frequent users of public libraries, perceiving them to be irrelevant creations of the Anglo culture. ${ }^{19}$ The rural American native student may not think of a library as a place to answer an information need or may be hesitant about approaching a library for assistance. In spite of these barriers, Virginia Streiff has shown that libraries, when used in combination 


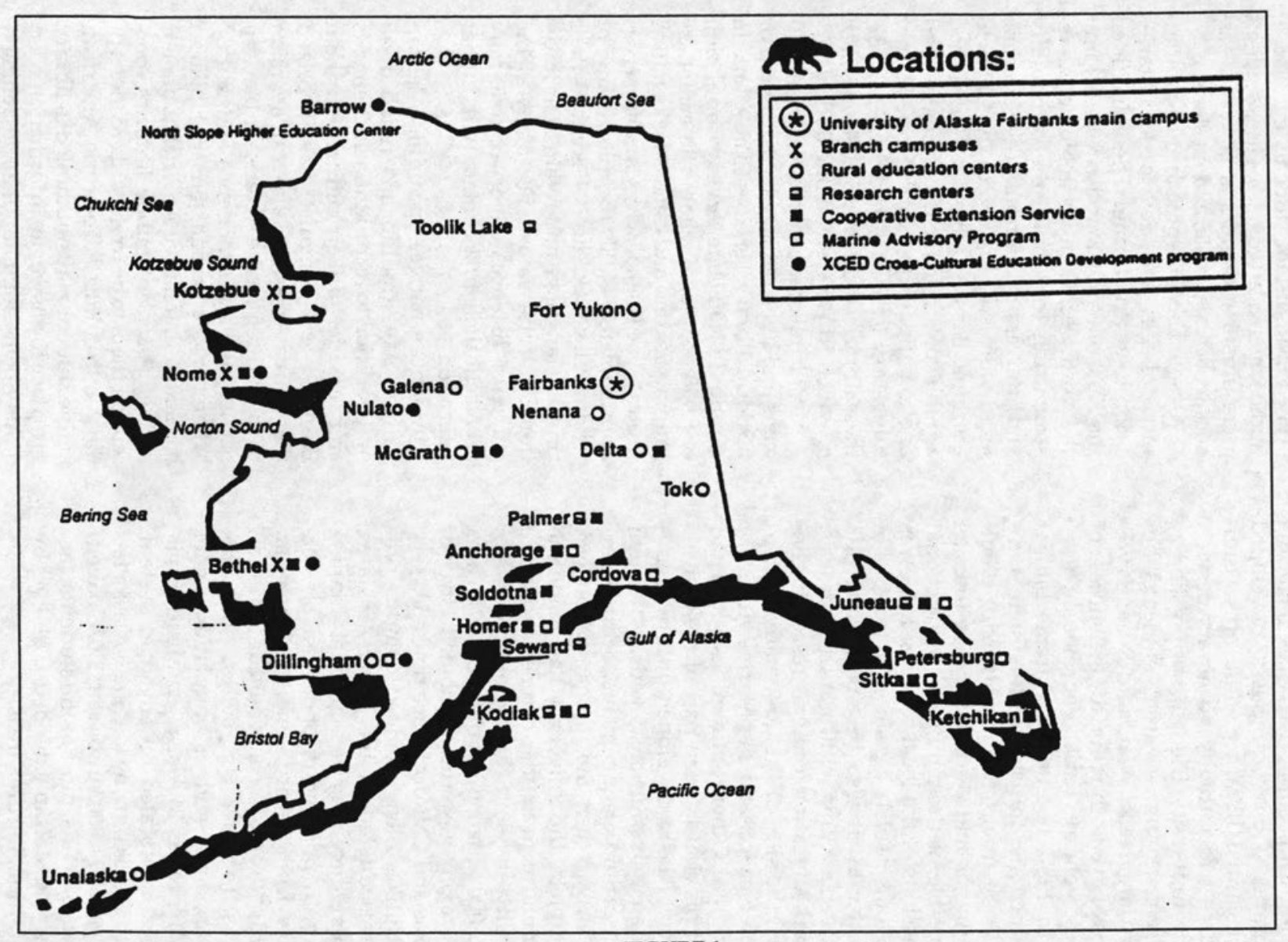


with appropriate curriculum, can substantially improve the language achievement of Eskimo children. ${ }^{20}$

\section{PROBLEM DEFINITION AND OUTCOME}

The problem faced by the Elmer E. Rasmuson Library in Fairbanks was, thus, twofold: providing library services to students in rural Alaska and overcoming the students' natural hesitancy about approaching a large academic library. In 1989 , based upon a report of the Distance Delivery Committee in the Rasmuson Library, the library instituted the Extended Campus Services (ECS) unit. ${ }^{21}$ It was created to meet four levels of patron information needs:

1. Students pursuing undergraduate degrees at a distance;

2. Graduate students, faculty, and researchers working at points remote from any research library;

3. Nondegree students taking courses at a distance;

4. Specific statewide patron groups needing access to government information or to the general and special collections of the library.

The first problem to be solved was communications between the student and the library in Fairbanks. Several statewide data networks, a university computer network, a commercial data network with access available from many of the state's villages, and a state government administrative network already existed. To take advantage of these networks, the library established two mail boxes on the University of Alaska Computer Network (UACN): a mailbox where students could request books and periodical articles on interlibrary loan and a reference mailbox where students could pose questions and have them answered. If students had access via the commercial data network or the state administrative network, they could access the university computer network as well.

The Rasmuson Library then instituted a toll-free number statewide. This number was an important factor since most students lived in areas of economic underdevelopment. Library administra- tors initially placed voice mail on the 800 number to save on personnel costs. We believed we had met Cookingham's first condition of access.

We then tackled the problem of awareness. Publicity was important because most students and faculty were initially unaware of any extended library services. A flyer was developed and distributed to all faculty who were headquartered off campus. Flyers were also distributed to the branch campuses.

The key to use of our service was faculty involvement. We aggressively pursued meetings with each group of rural faculty as they came to Fairbanks for orientation. We also decided to send a faculty member from the Rasmuson Library to each branch campus at least once a year for consultation and input review sessions. The purpose of the visit was to be twofold: to show the commitment of the Rasmuson Library to the rural educational mission and to learn from our rural colleagues and students the problems and needs they faced on a daily basis.

The key to use of our service was faculty involvement. We aggressively pursued meetings with each group of rural faculty as they came to Fairbanks for orientation.

The first point of contact for faculty and students was via the 800 telephone number or the electronic mailbox. A staff member who was trained in interview techniques took the request, transcribed it onto a form, and sent it to the reference librarian. The reference librarian conducted the library research, selected the materials, and passed the information to the extended campus services office, which sends the packet out to the student. The stated goal for turnaround time from receipt of request to mail out was forty-eight hours.

Originally all material was sent from Fairbanks via first-class priority mail. We did try to scan and digitize some periodical articles and send them over 
the University of Alaska Computer Network (UACN), but found it presented some major technical problems and was too time consuming. ${ }^{22}$ As facsimile machines became ubiquitous in Alaska, we added a facsimile machine to our unit and started routinely faxing materials to the rural areas.

\section{RESULTS}

We assumed that the demand for the service would be varied but relatively low in number since we presumed that the libraries in Nome, Kotzebue, and Bethel would provide library service to their students directly. This did not prove to be the case.

From fall 1989 through December 1990, we answered 768 information requests which came from over 90 Alaskan villages and towns. A geographic analysis of requests showed that our services were being delivered virtually to the entire state of Alaska. We did find that we handled significantly fewer requests from the Bethel region. It is no coincidence that the consortium library in Bethel had the largest single collection in rural Alaska, over 24,000 volumes.

During this period we had an enrollment of 8,087 students in rural Alaska, giving us a 10 percent use rate. While this use rate may seem low, 31 percent of these students were taking vocational, developmental, and noncredit courses that typically did not require the use of information resources.

More interesting has been the increasing degree of use. In fall 1989, 6 percent of all students used Extended Campus Services. In spring 1990, use had increased marginally to 6.4 percent of all students. By fall 1990, 10 percent of all students used the service. Figure 2 shows the increasing use of Extended Campus Services for the period indicated.

The stated goal for turnaround time was forty-eight hours. An analysis of turnaround time on requests revealed that 43 percent of all requests were sent out within forty-eight hours. In examining those requests which were not filled within the goal turnaround time, we found that, if a request was not filled within forty-eight hours, its turnaround time was substantially longer than the goal time and the delayed fill rate was related to the complexity of the request. In some cases, the delay in fill rate was artificially created. Some faculty requested assistance, but had no time limitation on the request. If we were handling a large number of requests at the time, these were sent to the back of the queue to wait.

\section{From fall 1989 through December 1990, we answered 768 information requests which came from over 90 Alaskan villages and towns. A geographic analysis of requests showed that our services were being delivered virtually to the entire state of Alaska.}

Additionally, as the number of requests increased, response time began to lag. Teaching faculty exacerbated the situation by assigning entire classes to use ECS at one time. Without additional resources, during high-use periods turnaround in forty-eight hours became increasingly difficult to achieve (see figure 3 ).

\section{CONCLUSION}

From the beginning we knew it was essential that clear, rapid communication between the library and ECS user was paramount. Using voice mail on the toll-free number was counterproductive to that goal. Hang-ups were numerous with voice mail, and messages left were few. Many students found using voice mail intimidating and cold. Very shortly after the institution of ECS, we eliminated voice mail in favor of staff answering the telephone from 8 a.m. to 5 p.m. An answering machine was installed to be used after 5 p.m. Interestingly enough, users were not as resistant to the answering machine as they were to voice mail.

Staff answering the telephone were given interview training to assist them in being responsive and sensitive to the needs of the ECS users. During this training, we 


\section{UAF RASMUSON LIBRARY}

\section{Extended Campus Services Requests}

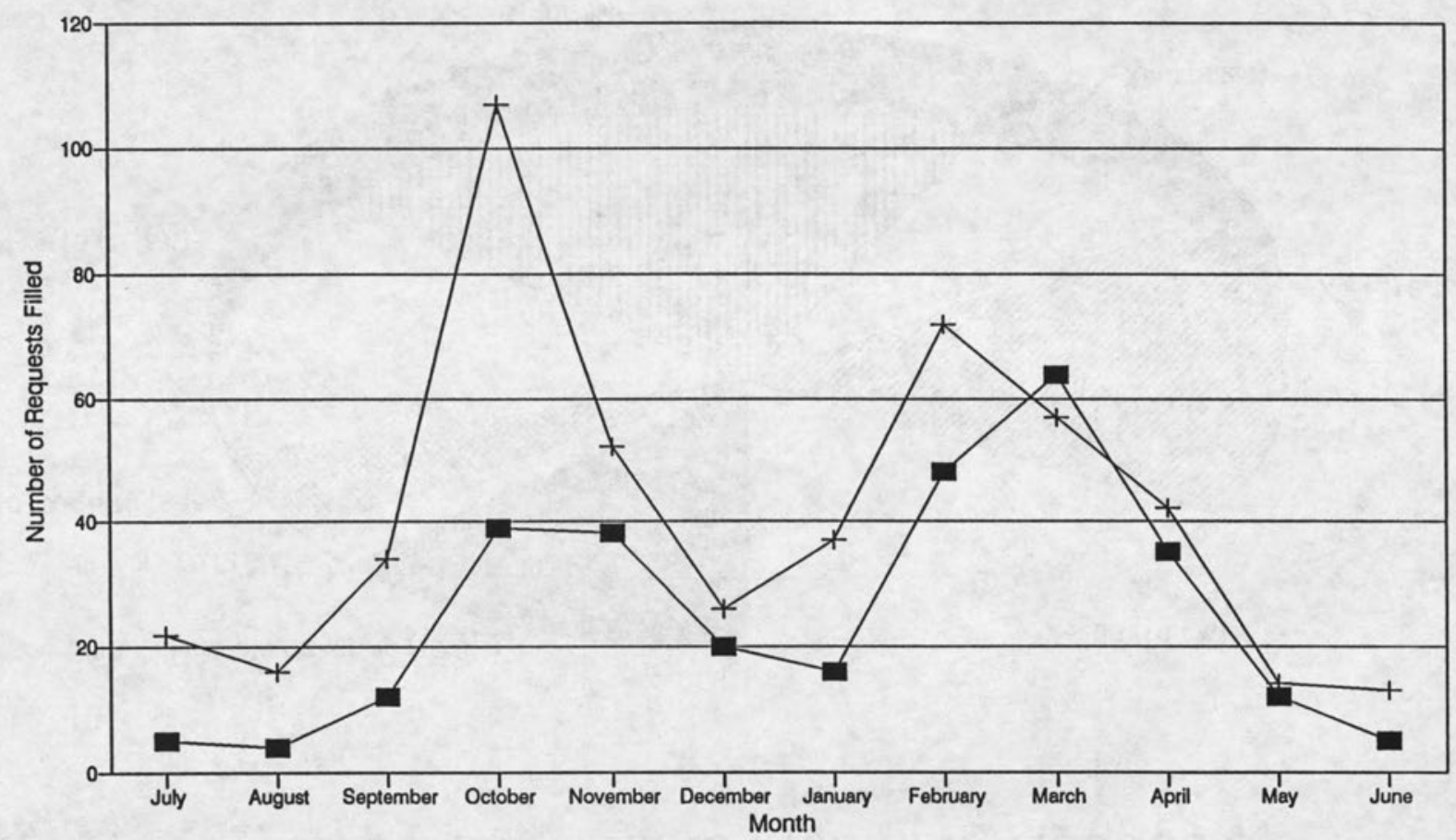

$-\mathrm{E}-\mathrm{FY} 90+\mathrm{FY} 91$ 


\section{Extended Campus Services Response Time to Incoming Requests}

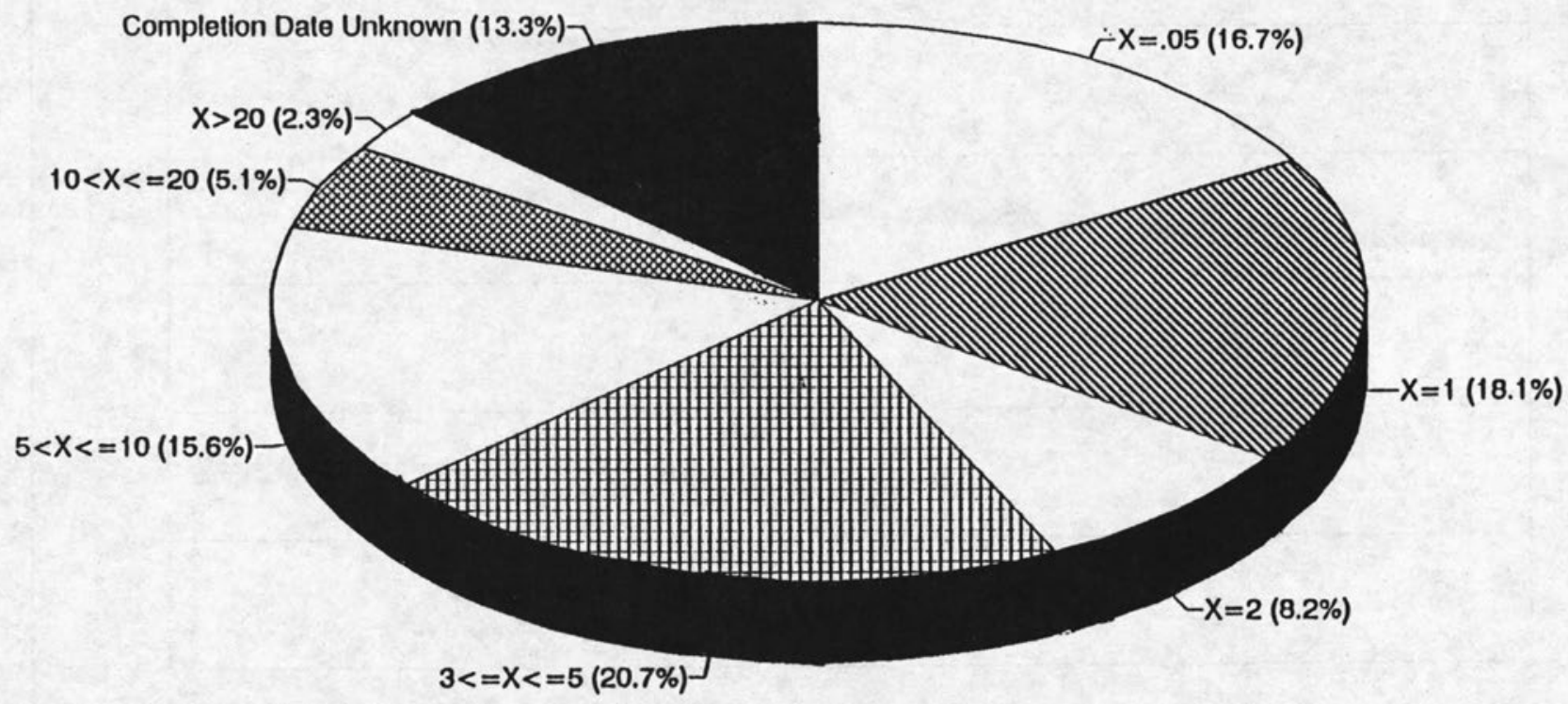

$X=$ Number of Days to Complete Request 
emphasized cross-cultural training, so that our staff were aware of some of the pitfalls when two individuals from different cultures communicate. An emphasis was also given to getting the most complete information possible.

This part of the process turned out to be the most problematic. In successfully building this service, one of the most important factors was outstanding reference interview skills. Some staff taking the requests were not librarians. They were not able to conduct the necessary in-depth reference interview. In almost all cases, the librarian had to call the requester back for further information or clarification of the information already in hand. The callbacks before beginning work on the request saved time in filling the request and also improved the level of use satisfaction.

Following the ACRL Guidelines for Extended Campus Library Services, ${ }^{23}$ a librarian was assigned to work directly with ECS students and faculty. This assignment was a crucial element in the success of the program since the librarian aggressively established ongoing relationships with faculty located on the rural campuses. This relationship was critical to improving service because we found that students would complain to their instructors about library service, but would not communicate this back directly to ECS staff. Rural faculty were willing to provide helpful constructive feedback for improvement of service.

We found that personal contact was the main way in which we communicated with students and faculty. The electronic mailboxes set up for communication purposes were not used much. We know that most students and faculty have access to a computer and modem. The University of Alaska's online catalog is available to students via three data networks with a local telephone call, yet few students used it to identify materials before calling ECS. We believe that the nonuse of electronic technology was because of a lack of familiarity and with online catalogs and dial-up networks. Accordingly, beginning in fall 1991, the library faculty began teaching a distance education course on information-seeking skills. A major objective of the course was to make rural students comfortable with using telecommunications to access the electronic library.

The one extremely popular and widely used electronic technology was telefacsimile. Almost every community had at least one fax-usually in the school or the village grocery store. Noneducational and business institutions were generous in allowing students to receive fax from the library on their fax machines. Costs for sending materials by telefacsimile were borne by the library as part of our ECS service package.

Some technical problems with fax had to be overcome. The quality of telephone lines was so poor that we often had to send materials at a much reduced transmission rate, substantially increasing the cost of the fax. Fax machines in the village often shared the line with other uses. Getting the receiver to hook the fax up to the line and to leave it on the line long enough for the transmission was sometimes a challenge.

Kascus and Aguilar postulated that if a campus library assumed centrally all responsibility for its students, the development of the service would come at the expense of the campus library program. ${ }^{24}$ In this case, their hypothesis proved to be true.

While Judith Ream and Norman Weston reported an increase in funding specifically to cover the costs of new extension services, ${ }^{25}$ the Rasmuson Library received no additional funding to assume the responsibility for providing library service to rural students, even though the review of the service by the college responsible for distance education was highly favorable.

As much as a library may believe that its off-campus students and faculty need information resources, the on-campus political environment must be factored into the building of such a program. Virginia Witucke has stated that aggressive marketing and activist programs characterize the successful off-campus program. ${ }^{26}$ While Witucke intended the 
off-campus faculty and students to be the primary target of such marketing, on-campus marketing and public relations must also be considered. In our case, some on-campus faculty were hostile to the ECS program. Since the ECS librarian often actually carried out the library research for the off-campus faculty member and student, on-campus faculty perceived that off-campus users received preferential treatment over oncampus users. The development of the library skills course for distance delivery was done in part to involve the rural student more directly in the library research experience and to overcome this objection.

Library faculty were not enthusiastic about extending a new service without additional funding. Since the library was already suffering from inadequate funding to support the on-campus programs, the reallocation of funds to a new pro- gram was not initially well received. Some library faculty also shared the concern of the teaching faculty about providing a higher level of service to off-campus users than was being given to on-campus users.

Most, if not all, librarians would agree that the optimum situation is for students and faculty to have direct electronic and physical access to a library. The reality of distance education is that this is often impossible. To meet the needs of these users, librarians must think of new approaches and reexamine their ideas of what constitutes an educational library experience. In the oncampus library setting, we hope our students and faculty will empower themselves by using the information and services resident in our libraries. Using different, but equitable means, we must provide the opportunity for our distance learners to empower themselves as well.

\section{REFERENCES}

1. Carnegie Commission on Higher Education, Less Time, More Options: Education beyond the High School (New York: McGraw-Hill, 1971); Leland Medsker et al., Extending Opportunities for a College Degree: Practices, Problems, and Potentials (Berkeley, Calif.: Center for Research and Development in Higher Education, University of California, Berkeley, 1975).

2. Arthur T. Hamlin, "College and Research Library Contributions to Adult Education," Library Trends 8:51-61 (July 1959).

3. I. T. Littleton, "The Off-Campus Library Services of Universities," College \& Research Libraries 20:300-306 (July 1959).

4. Glenn R. Wilde, "Coming to Grips with the Information Age in Rural America," Bulletin of the American Society for Information Science 10:20-22 (June 1984).

5. Russell L. Dobson and Judith Dobson, “CE/MORE: A Rural Staff Development Model," paper presented at the annual meeting of the National Rural Teacher Education Conference, Bellingham, Washington, October 9-11, 1985.

6. American Library Association Task Force to Review the Guidelines for Extended Campus Library Services, "ACRL Guidelines for Extended Campus Library Services," College \& Research Libraries News 51:353-55 (Apr. 1990).

7. Ibid., p.355.

8. Marie Kascus and William Aguilar, "Providing Library Support to Off-Campus Programs," College \& Research Libraries 49:29-37 (Jan. 1988).

9. William Critchley, "The Open University-A Challenge to the Public Library," SLA News 92:325-28 (July/Aug. 1969).

10. Sarah B. Askew, "New Jersey's Service to Extension Students," ALA Bulletin 26:47-48 (Jan. 1932).

11. Almere L. Scott, "University Extension Division: Point of View," ALA Bulletin 32:978-79 (Oct. 1938).

12. Richard C. Haycock, "The ICLIS Report," paper presented at the 53rd annual meeting of the American Society for Information Science, Toronto, 1990; Glenn R. Wilde, "An Educational and Informational Delivery Network for Rural Intermountain Communities," Bulletin of the American Society for Information Science 10:20-22 (June 1984). 
13. Arthur Podolsky, Public Libraries in 50 States and the District of Columbia: 1989 (Washington, D.C.: U.S. Dept. of Education, Office of Educational Research and Improvement, 1991), p.9.

14. Ibid., p.67.

15. Robert M. Cookingham, "Delivering Off-Campus Library Services in Northern California," paper presented at the Off-Campus Library Services Conference, Oct. 14-15, 1982, St. Louis, Mo.

16. Margaret K. Wood, "University of Alaska's Outreach Program Develops Approach to Delivery of Off-Campus Library Services in Rural Alaska," in Off-Campus Library Services Conference Proceedings, ed. Barton M. Lessin (Mt. Pleasant, Mich.: Central Michigan University Press, 1986) p.238-61; Rosemary E. Ross, "Distance Delivery of Northwest Academic Library Services: ACase Study," PNLA Quarterly 53:14-16 (Spring 1988).

17. Thomas A. Gaylord et al., Statistical Abstract 1988 (Fairbanks, Ala.: Office of Institutional Research, University of Alaska System of Higher Education, 1989) p.4-29.

18. Elizabeth Brandt, "Native American Attitudes toward Literacy and Recording in the Southwest," Journal of the Linguistic Association of the Southwest 4:185-95 (July 1981).

19. Susan Hollaran, "Rural Public Library Service to Native Americans," Rural Libraries 10:31-48 (1990).

20. Virginia Streiff, Reading Comprehension and Language Proficiency among Eskimo Children (New York: Arno, 1978).

21. Elmer E. Rasmuson Library Distance Delivery Committee, "Final Report" (June, 1988); unpublished manuscript, University of Alaska Fairbanks, Fairbanks, Alaska.

22. Steve Smith, "Sense and Nonsense about Distant Document Delivery," in Promises to Keep: Reaching the Distance Education Learner, ed. Charles Blood (Anchorage, Ala.: University of Alaska, Division of Rural Alaska, 1986) p.151-60.

23. American Library Association, "ACRL Guidelines for Extended Campus Library Services," p.355.

24. Kascus and Aguilar, "Providing Library Support to Off-Campus Programs," p.33.

25. Judith Ream and Normal Weston, "The Effects of Innovative Extended Library Services on Total Library Operations," in The Off-Campus Library Services Conference Proceedings, ed. Barton M. Lessin (Mt. Pleasant, Mich.: Central Michigan University, 1983) p.129-37.

26. Virginia Witucke, "Off-campus Library Services: Leading the Way," College \& Research Libraries 51:252-57 (Mar. 1990). 


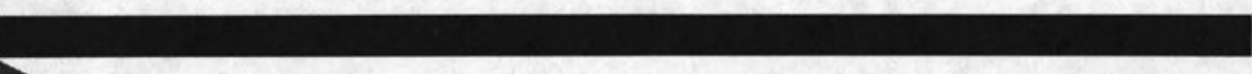

\section{ASSOCIATION OF COLLEGE BESEARCH LIBRARIES}

OVER 10,000 PROFESSIONALS

SHARING IDEAS

PROVIDING OPPORTUNITIES

FINDING SOLUTIONS

$\nabla$ Build your professional skills and expertise through more than 100 educational programs held each year. Experience the challenging programs offered at the ACRL National Conference, the ALA Annual Conference, preconferences, and local continuing education courses.

$\nabla$ Benefit from valuable research and practical ideas by reading ACRL's varied publications-College \& Research Libraries, College \& Research Libraries News, Choice, Rare Books \& Manuscripts Librarianship, Books for College Libraries, CLIP Notes.

$\nabla$ Connect with colleagues from around the state, country, and around the world.

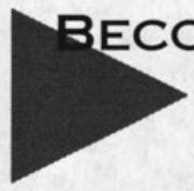

Association Of

Get your membership information by calling $800-545-2433$, ext. 2517 , by faxing this form to $312-280-2520$, or by sending this form to ACRL, $50 \mathrm{E}$. Huron St., Chicago, IL 60611.

C O L L E G E

\& RESEARCH

\section{Name}

LIBRARIES

\section{Address}

